cut through confusion and distortions to the core of a problem, pursued a point to its conclusion, and admitted it when he failed to find sure answers. Whether writing history, teaching a class, preparing a paper for a professional gathering, or reviewing a book, he insisted on the highest standardsand was always his own most severe critic.

Many who never met Charles Cumberland know and admire his scholarship. His friends, colleagues, and students remember the man as well. He was the soul of integrity, insisting always that intellectual honesty must guide human conduct. He condemned injustice, and had an unusual capacity to feel compassion for others. He was a gentle man who liked and trusted people, and his sense of personal dignity would never permit him to violate the dignity of another. He was utterly devoid of pompousness, and his quiet humor was most often directed at himself.

Charles Cumberland was a talented scholar and a complete human being. The profession will miss his scholarship; those who knew him will also miss the man.

North Carolina State University,

David C. Bailey Raleigh, Nortb Carolina

\title{
Howard Francis Cline (1915-1971)
}

H OWARD CLINE was stricken with a heart attack at his desk in the Library of Congress on June 8, 1971. His death removes from our scene the most active and best known Latin American historian of his generation.

Howard Cline's most celebrated book, The United States and Mexico, and its sequel, Mexico, Revolution to Evolution, are famous as informed expositions of Mexican history. The two books were designed as explanations of modern Mexico in historical terms, as works to be read by anyone interested in the subject. They represent summary popularization at its most effective. Their material is full, their organization clear, their tone that of informal communication. They provide basic historical information and interpretation, as well as the kinds of graphic, factual, and statistical detail that are most informative.

Persons familiar only with these two books have sometimes been surprised to discover that Howard Cline took additional delight in research scholarship of the most meticulous and demanding kind. This aspect of his work appeared principally in the form of journal articles, and most dealt with historical problems of colonial New Spain. A full study of the Mexican Indian calendar was nearly completed at his death. Those of us privileged to work with him on the ethnohistory volumes of the Handbook of Middle American Indians can appreciate further the painstaking labors he accom- 
plished on the bibliography of Fray Bernardino de Sahagún and on other topics of native history. He was the one who originally conceived those volumes, and when they are published it should be to him more than to anyone else that their success should be attributed.

Under Howard Cline's leadership during the past two decades the Hispanic Foundation has become the active center of Hispanic studies that we all know. The vistor's impression always was of a staff functioning on a variety of projects and united in its loyalty to the director. Despite the easy atmosphere of the Foundation, its accomplishment has been enormous, and the fact is a testimony to Howard Cline's administrative skills, his ability to inspire people and to delegate responsibility in productive ways, and his capacity for keeping a number of undertakings going forward at once. His contributions to the Handbook of Latin American Studies were extensive and valuable, and as often as not they represented responses to editorial emergencies or to unexpected deadlines at times when no one else was available. Few people in Washington did more in any field to arrange meetings, secure funds, make recommendations for jobs, and in other ways provide help for scholars young and old.

To summarize and pay tribute to so rich a career is no easy matter. $\mathrm{He}$ was a person of prodigious knowledge, of profound insights concerning past and present, and of unbounded energy. Each of his friends, and there were thousands, will have his own memory of an extraordinary personality and of the numerous ways in which it was expressed. We remember him at international meetings at Vienna or Mar del Plata, distinguished in his red waistcoat, the center of a convivial group, surrounded by laughter, telling his famous stories; or on a speaker's platform explaining the intricate minutiae of the land titles of Oztoticpac; or as a member of a committee to award a prize or organize a new conference or draft a constitution, expertly summarizing the problem and outlining the steps to be taken; or at home with family and friends, in casual but enthusiastic conversation, recounting some bizarre experience or commenting in his incisive and humorous way on people and events. He was a wonderful husband and father, a skillful administrator, a dedicated teacher, an original and imaginative interpreter of the Hispanic world, and a help and inspiration to innumerable people who sought his aid.

Charles Gibson 